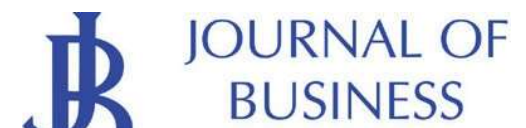 \\ UNIVERSIDAD DEL PACÍFICO
}

\section{Analysis of Product Mix, Capacity Release, and Utilities}

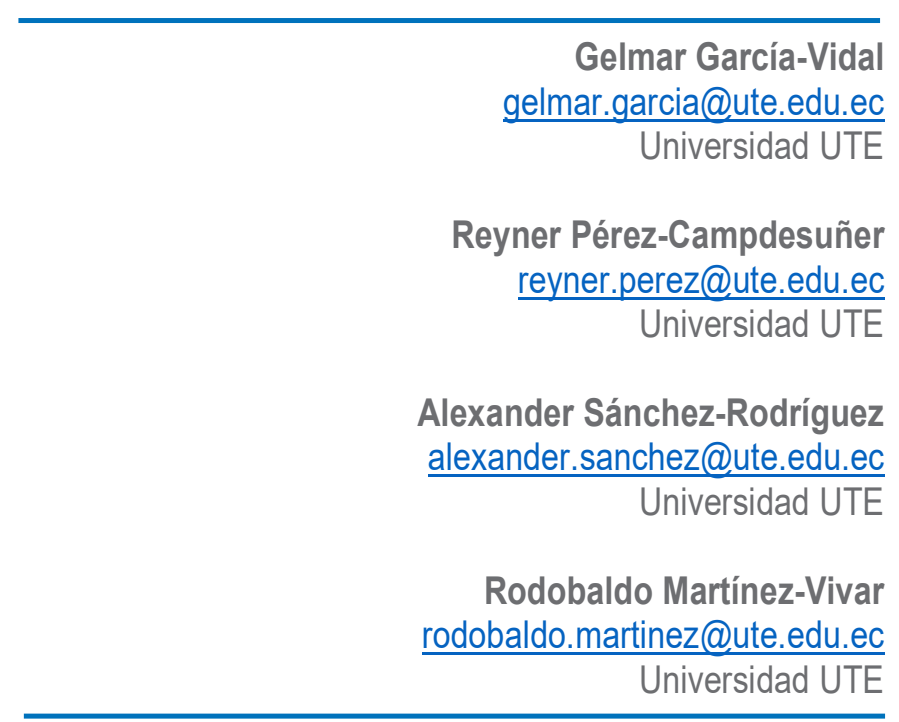

\begin{abstract}
In this study, we use a technique based on the cost - volume - benefit method in order to have economic and financial information on the right mix of products for an organization to achieve the expected results. The method comprises the usual components: unit price, unit variable cost, operating expenses, and financial expenses. The technique consists of 10 steps to create as many scenarios as necessary in which to evaluate the mix of products, the installed capacity, and the profits that ultimately lead to success. We apply this method to a small machine workshop. The results show that the proposed method indicates the desired level and mix of utilities. This research provides the information to entrepreneurs to help them make the most pertinent decisions for the negotiation processes in order to achieve the expected results.
\end{abstract}

Keywords: Negotiation; Cost - Volume - Profit Analysis; Product-Mix Decision; Capacity expansions. 


\section{Análisis del mix de producto, liberación de capacidad y utilidades}

$\begin{array}{r}\text { Gelmar García-Vidal } \\ \text { gelmar.garcia@ute.edu.ec } \\ \text { Universidad UTE }\end{array}$
Reyner Pérez-Campdesuñer
$\frac{\text { reyner.perez@ute.edu.ec }}{\text { Universidad UTE }}$
Alexander Sánchez-Rodríguez
$\frac{\text { alexander.sanchez@ute.edu.ec }}{\text { Universidad UTE }}$
Rodobaldo Martínez-Vivar
rodobaldo.martinez@ute.edu.ec
Universidad UTE

\section{Resumen}

En este estudio utilizamos una técnica basada en el método costo - volumen - beneficio con el fin de tener información económica y financiera sobre la combinación adecuada de productos para que una organización logre los resultados esperados. El método comprende los componentes usuales: precio unitario, costo variable unitario, gastos de operación y gastos financieros. La técnica consta de 10 pasos para crear tantos escenarios como sean necesarios en los que evaluar el mix de productos, la capacidad instalada y las utilidades que finalmente conducen al éxito. Aplicamos este método a un pequeño taller de máquinas. Los resultados muestran que el método propuesto indica el nivel deseado y la combinación de utilidades. Esta investigación brinda la información a los empresarios para ayudarlos a tomar las decisiones más pertinentes para los procesos de negociación con el fin de lograr los resultados esperados. 


\section{Introduction}

Entrepreneurs are negotiators par excellence (García Vidal, 2006; Scalzo \& García Álvarez, 2018). However, the social needs of their products and the possibilities to satisfy them restricts the actions of small and medium entrepreneurs as negotiators. The negotiations in the areas of buying and selling decide to a great extent the future results of a company. However, many small entrepreneurs negotiate using intuition, experience, and in the best case, calculations of isolated indicators. Therefore, these negotiators accept commercial agreements without fully assessing their contribution to their company. Hence, the results of their actions do not guarantee the success of their company, but rather commit it to certain actions. In general terms, the economic and financial information that are available during a negotiation are incomplete and untimely and do not contribute to the correct decisions.

Negotiation, as a defining moment in the life of the company, must be consciously and carefully planned by small entrepreneurs so that it guarantees the anticipated achievement of business efficiency (Agndal, Åge, \& Eklinder-Frick, 2017; Brett \& Thompson, 2016; Flint, 1990; García Vidal, 2006). Not doing so provokes (1) the ignorance of the state of commercial advantages or disadvantages with customers and suppliers, (2) decrease in sales volume, (3) acquisition of low quality work objects or in inadequate quantities, (3) late deliveries or receipts of supplies, (4) the increase in accounts receivable and pay out of term, (5) the inadequate mix of products, (6) the increase in inventories and expenses of operations, among others. And as a result of all this, the decrease in profits and liquidity that is the well-known risk to the future of the company.

The specialized literature on negotiating has focused its analysis on the socio psychological aspects of negotiating on both the individual and collective levels. Among the topics addressed are the styles, abilities and negotiating behavior (Clenney, Maurer, \& Miles, 2013; Côté, Hideg, \& van Kleef, 2013; Chapman, Miles, \& Maurer, 2017; Chuah, Hoffmann, \& Larner, 2014; De Dreu, Weingart, \& Kwon, 2000; Fisher, Ury, \& Patton, 2011; Forgas, 1998; Lumineau \& Henderson, 2012; Miller, 2014; Saorín-Iborra \& Cubillo, 2018; Stevens \& Gist, 1997; Zohar, 2015), negotiating strategies and tactics (Alavoine, 2012; Alavoine \& Estieu, 2015; Baek \& Kim, 2007; Fisher et al., 2011; Ganesan, 1993; Geiger, 2017; Holmes, Beitelspacher, Hochstein, \& Bolander, 2017; Lumineau \& Henderson, 2012), the management of power (Wiltermuth, Raj, \& Wood, 2018), influence of religious beliefs (Richardson \& Rammal, 2018), ethics (Mason, Wiley, \& Ames, 2018), influence of language and cultural differences (Alvarez, Taylor, \& Gomez, 2017; Chuah et al., 2014; Peleckis, 2014; Ribbink \& Grimm, 2014), and the negotiation climate (Sánchez-Anguix, Julián, Botti, \& García-Fornes, 2013). The abundance of these aspects is in contrast to the dominance of the economic and financial factors that affect the process (Agndal, 2007; Domínguez Rodríguez \& Téllez Sánchez, 2011; Essa, Dekker, \& Groot, 2018; Fisher et al., 2011).

This disparity leads to the conclusion that despite the importance of the negotiation to the success of the company, there is a lack of research about the economic and financial aspects that must be accounted for in that process (Agndal, 2007; Essa et al., 2018; Saorín-Iborra \& Cubillo, 2018). We argue that although it is necessary to pay attention 
to the subjective aspects of the negotiator in particular and the process in general, economic and financial information is a defining variable that influences the planning, decisions, and results of the negotiation process.

Thereby, we discover two advantages in the commercial negotiating process: the subjective that is inherent in the psychology of the negotiating subject; the objective that is characterized by the use of economic and financial variables, which must be used by the subject to define the goal of a negotiation. The experience that small entrepreneurs develop in the negotiation world, although often intense, do not always incorporate the adequate analysis methods to achieve the maximum results in the negotiating process (Chang, Cheng, \& Trotman, 2013; de Lima, Ferro, Bortoluzzi, Puttow Southier, \& DBatistus, 2018). The main shortcomings at the time of negotiation lie in the lack of knowledge of the economic and financial information, a mix of products suitable to achieve a desired volume of profits or at least equilibrium, and the necessary capacities to achieve it; all of which supposes invaluable information for the correct management of the company.

The objective of the research is to design and apply a technique that is based on the cost - volume - benefit method (de Lima et al., 2018; Laureth, Wernke, Heberle, \& Rufatto, 2018; Răscolean \& Rakos, 2017; Ribeiro Alves da Silva, Figueirêdo Cireno, \& Santana Bonfim, 2017; Said, 2016) to solve the limitation of inadequate economic and financial information during negotiation.

The next section reviews the literature on negotiations, product mix, productive capacities and in particular the effects of accounting information on the success of negotiations. In Section 3, we develop in detail the method used in the investigation. Section 4 is the results of the case study on the practice of a small business. In Section 5 we discuss the results, and Section 6 concludes.

\section{Literature Review}

Like any other administrator, small and medium entrepreneurs are permanently involved in negotiations of a different nature. Therefore, negotiating, and doing well, acquires a singular importance for their current and future stability and therefore is a fundamental part of the management process both internally and externally for the organization (Brett \& Thompson, 2016; Essa et al., 2018; García Vidal, 2006; Geiger, 2017; Richardson \& Rammal, 2018; Saorín-Iborra \& Cubillo, 2018). This research devotes its attention to the negotiation external to the organization.

Several authors agree that negotiations are complex processes involving two or more parties with needs, goals, aspirations and resources with the aim of reaching agreements on a given issue which will produce an expected gain or effect (Alavoine \& Estieu, 2015; Chang et al., 2013; Chapman et al., 2017; Essa et al., 2018; Saorín-lborra \& Cubillo, 2018; Van den Abbeele, Roodhooft, \& Warlop, 2009). What is not clear, in the case of trade negotiations, is whether reaching an agreement involves dynamically anticipating the economic and financial situations of the negotiating parties during subsequent purchases and sales (Chang et al., 2013; Geiger, 2017; Saorín-lborra \& Cubillo, 2018). 
In other words, negotiations need to reconcile the interests of different parties with the minimum of dissatisfaction but also must account for the objectives of all parties.

The commercial situation (relationship between the social needs of their products and the possibilities to satisfy them) conditions the actions of small and medium entrepreneurs and their companies as a whole when facing a negotiating process. From the point of view of the seller, the most complex situation arises when the supply is greater than the demand. Acceptance of an agreement can compromise performance in future periods if the future implications of local or individual effects are not identified. This is turn may endanger the continuous improvement of the efficiency of the company.

The negotiation in its subjective component is centered in a socio - psychological process in which different positions and different attitudes manifest themselves both individually and collectively. This component is widely treated in the literature (Côté et al., 2013; Chapman et al., 2017; De Dreu et al., 2000; Fisher et al., 2011; Holmes et al., 2017; Mason et al., 2018; Ribbink \& Grimm, 2014; Saorín-lborra \& Cubillo, 2018; Wiltermuth et al., 2018) and has become the primary approach to negotiating behavior.

In the literature consulted (Côté et al., 2013; Chapman et al., 2017; Chuah et al., 2014; De Dreu et al., 2000; Geiger, 2017; Richardson \& Rammal, 2018; Saorín-lborra \& Cubillo, 2018; Wiltermuth et al., 2018), the scarce allusion to the economic and financial variables in the commercial negotiation process is notable, although some studies have combined economic and financial aspects with behavioral perspectives to understand negotiating behavior (Chang et al., 2013; Drake \& Haka, 2008; Essa et al., 2018; Van den Abbeele et al., 2009).

The studies on the research trends in negotiation over the last two decades (Agndal, 2007, Agndal et al., 2017, Gunia, Brett, \& Gelfand, 2016) clearly make evident the limitation in the approach (See Figure 1) that calls for attention to the objective aspects of the negotiation as well as to the subjective ones.

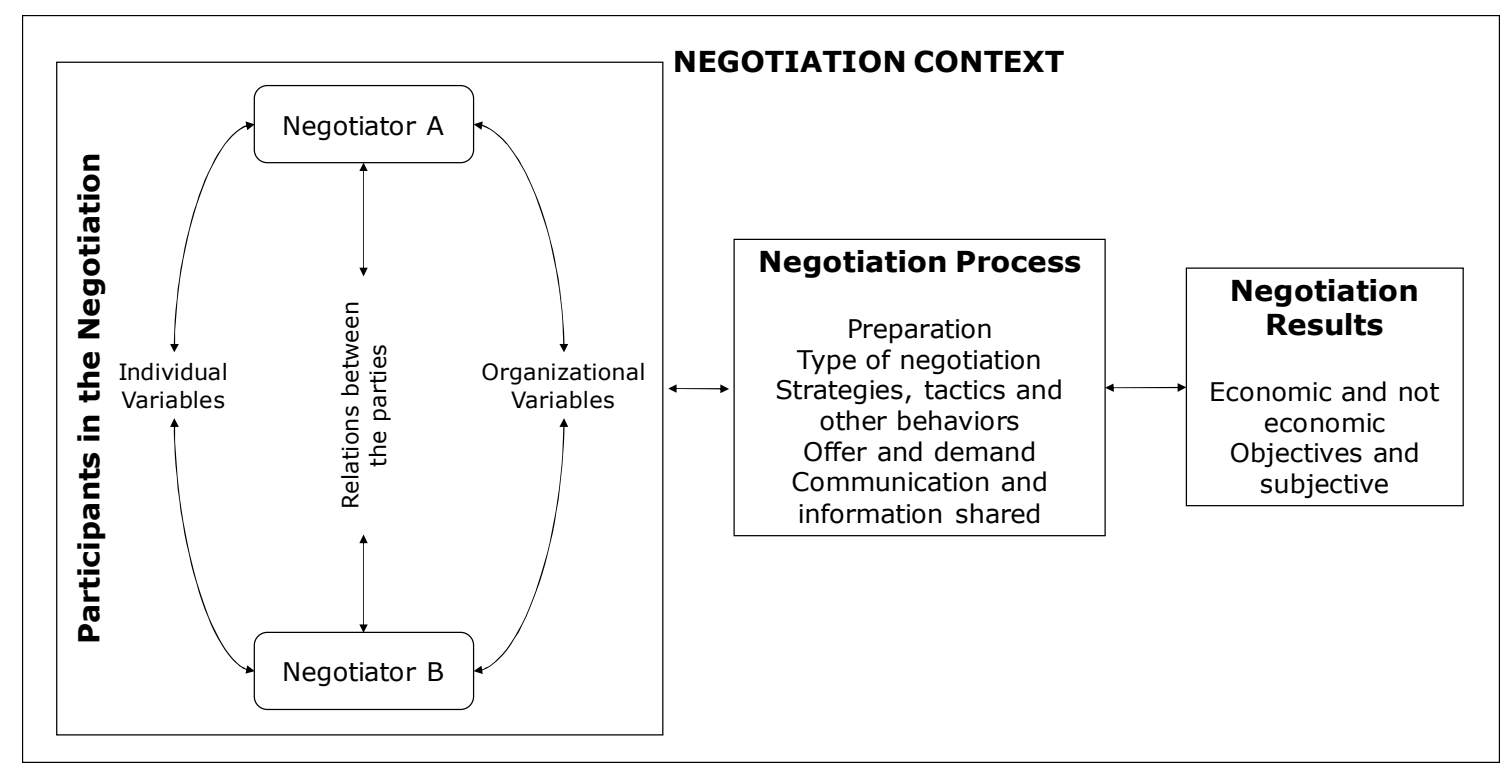

Figure 1. Trends in negotiation research.

Source: Based on Agndal (2007), Agndal et al. (2017), and Gunia et al. (2016). 
It is evident that it is not possible to demean the preparation of a negotiator in the subjective component that defines the procedure of that component (Chapman et al., 2017), only that it is necessary for entrepreneurs to make use of the economic variables to decide the goals of negotiation (Agndal, 2007; Chang et al., 2013; Essa et al., 2018).

The economic and financial variables are those that show the essence of the objective component of the commercial negotiation and therefore of the planning process. It is therefore necessary to assess the use and functioning of these variables (Chang et al., 2013). Negotiators must evaluate different variables such as sales, prices, variable costs, contribution margin, operating and financial expenses, net profit, etc. (Domínguez Rodríguez \& Téllez Sánchez, 2011; Răscolean \& Rakos, 2017; Said, 2016; Yuan, 2009). Some studies have found that negotiators with economic and financial information, particularly a cost-volume-profit analysis (Chang et al., 2013, Drake \& Haka, 2008, Essa et al., 2018, Van den Abbeele et al., 2009), have better results in negotiation with external adversities, such as adverse market conditions or small and medium entrepreneurs (Chapman et al., 2017; de Lima et al., 2018; Said, 2016).

Attempts to answer the questions about "what to negotiate" have received much less attention than "how to do it". This paradox reflects that the how depends on what. In this order of things, it is important to determine what mix of products while accounting for productive capacities and the demand (Fay, Xie, \& Feng, 2015; Gong \& Hu, 2008; Linhares, 2009; Tsai, Chen, Leu, Chang, \& Lin, 2013). Therefore, there is a need for a method that contributes to evaluate the most advantageous mixture of these factors to face a negotiation and to obtain the expected results.

The negotiator, prior to negotiating, must know the amount of each product that can be produced in a unit of time by his company. This study is carried out with the installed capacities to understand their real possibilities and the combinations that can be achieved in volumes and in proportions between the products with less capacity for various reasons and the products with more. The determination of the right mix of products is an important decision when negotiating since its composition and depth have a great impact on the final results, planning sales, and the costs of products (Fay et al., 2015 Fernandes, Gouveia, \& Pinho, 2012; Gong \& Hu, 2008; Linhares, 2009; Tsai et al., 2013).

The management of productive capacities enables the realization of a mix of products that contributes to achieving the maximum possible profits and the efficiency of the company (Fernandes et al., 2012; Gong \& Hu, 2008; Linhares, 2009; Tsai et al., 2013). To achieve efficiency, it is necessary to take into account the types of products that fit the productive process; it is necessary to start from the classification of the excluded products (those products that need the same means of production for their production) and not exclusive (those that can be produced indistinctly, because they do not need the same means of production), according to the use of technical equipment.

In the case of excluded products, this analysis is of special interest. The definition of the mixture is made more complicated because with the same technical equipment, different products can be produced and the equipment can only produce a type of goods in a period of time that is determined basically by demand. In this case it is necessary to make the process more flexible in order to make other goods or services, whether similar 
or different, that increase the satisfaction of customers through the variety of offerings (Fernandes et al., 2012; Gong \& Hu, 2008; Linhares, 2009).

\section{Methodology}

The cost - volume - benefit method has the following components: unit price, unit variable cost, operating expenses, and financial expenses (de Lima et al., 2018; Laureth et al., 2018; Răscolean \& Rakos, 2017; Ribeiro Alves da Silva et al., 2017). We also add the following elements: the installed capacity expressed in terms of each product, the distribution coefficient of the "quantity ceded" and the resulting mix of products, the adjustment factor, and the release of installed capacity.

The method has 10 steps to create as many scenarios as necessary to identify the mix of products relative to the installed capacity to generate profits for the company. These steps help to explain the way to achieve the desired profits or the point of balance with a certain composition of products. The model will then serve as a guide for the negotiation of the products that the company produces and puts on sale.

The proposed steps involve the application of formulas that favor calculations and allow the subsequent automation of the analysis, which is extremely useful in particular when dealing with many products.

Step 1: Determine the amount of operating expenses, financial expenses, and other income if you only want to work with the breakeven point, and add the desired profits if you need to investigate beyond that point. In addition, it is necessary to know the prices and unit variable costs as well as the potential capacities for each type of product.

Step 2: With the collected data, you must proceed to calculate the amount necessary to reach the desired amount as if you were going to sell a single product that the company produces and sells.

$$
I d=G O+G f-O i+U_{d}
$$

Where:

Id: Amount desired

GO: Operating expenses of the company for the period under analysis.

Gf: Financial expenses of the company for the period under analysis.

Oi: Other income that the company can access.

$\mathrm{U}_{\mathrm{d}}$ : Utilities desired (only if you want to analyze beyond the equilibrium point).

The necessary amount calculations are made separately for each product.

$$
Q_{n}=\frac{I d}{\left(p u_{n}-c v u_{n}\right)}
$$


Where:

Qn: Required amount of product sales " $n$ " to reach the desired amount.

Id: Amount desired

$\mathrm{pu}_{\mathrm{n}}$ : Unit price of product " $\mathrm{n}$ " submitted for analysis.

$\mathrm{cvu}_{\mathrm{n}}$ : Unitary variable cost of product " $\mathrm{n}$ " subjected to analysis.

Step 3: The percentage of installed capacity that would be occupied if only one of the products was made at a time.

$$
C d_{n}=\frac{Q_{n}}{Q t_{n}}
$$

Where:

$\mathrm{Cd}_{n}$ : coefficient between the necessary quantities of product " $\mathrm{n}$ " and the total of possible quantities of that product according to the company's operational capacity.

Qt $t_{n}$ : total amount that, of the product " $n$ ", the company can do according to operational capacity.

Step 4: The products from which more sales are needed to reach the desired amount are sorted down to the one that needs to sell the least to reach that goal. This sorting establishes an order of priorities that will be indispensable for the next steps.

Step 5: The existing range between the sales of the product that you need to sell the most that is calculated by subtracting the sales from the one that needs to sell the least to reach the desired amount. This range will identify the number of units that can be mixed and that must be strictly adhered to, since redistributing more than that amount will be economically impossible and will make the analysis that is explained unviable.

$$
R=Q_{p 1}-Q_{p n}
$$

Where:

$\mathrm{R}$ : range of quantities that is established between the sales of the product that needs to sell the most to reach the desired amount and the one that needs to sell the least it.

Qp1: indispensable amount to sell for the product that needs to sell the most to reach the desired amount.

Qpn: Quantity indispensable to sell for the product that needs to sell the least to reach the desired amount.

The starting point to create scenarios is the product that needs to sell the most to reach the desired amount that takes a number of units that as a rule are equal to or less than the range as explained above, which will be called "amount transferred".

Step 6: The way in which the "ceded amount" is distributed among the remaining products is estimated with a distribution coefficient that is expressed in decimal values that are less than one if there are several products and are equal to one if it is a single 
product. The coefficient is then used to multiply the product by the "quantity assigned" for the amount of that product.

$$
Q c t=\left(c f_{n}\right) Q c t
$$

Where:

Qct: The total assigned amount decided by the management that must be within the range calculated before.

$\mathrm{Cf}_{\mathrm{n}}$ : Coefficient for each product that designates the "quantity assigned".

Step 7: The "adjustment factor" is calculated by product and is the result of dividing the quantity that each product showed in the calculation for Step 2 that now needs more to sell. This result is a coefficient that serves to adjust the quantities assigned to the different products by the technique explained in Step 6 which determines how many products of each type will be sold to reach the desired amount.

$$
Q r_{n}=\left(c f_{n}\right) Q c t\left(\frac{Q_{n}}{Q 1}\right)
$$

Where:

$\mathrm{Qr}_{\mathrm{n}}$ : total units needed to sell to reach the desired amount.

Step 8: After the previous results, what level the installed capacity should be at should be evaluated by adding the percentages of the total capacity that the production of each one represents. This will determine how much capacity has been released or not. If it is enough, then the company will be in a very favorable situation, especially when the company is experiencing demand that is greater than the supply. In this situation, the company needs to expand capacities to sell more as the market is captive and more profit is possible.

$$
C o \geq C d_{1}+\cdots+C d_{n}
$$

Where:

Co: The operational capacity of the company for the selected product mix that is between its total operative capacity and what it needs.

$\mathrm{Cd} 1+\ldots+\mathrm{Cdn}$ : It is the sum of the various occupancy coefficients of the installed capacity that have covered the production decisions calculated according to the formula in the previous step.

This sum can never be greater than the operative capacity, because then the decision would be illusory and therefore unattainable.

Step 9: There are infinite variations that entrepreneurs can try until they find the one that seems best for them and that in their opinion is feasible to carry out. However, the customer has the last word, but having infinite variations is very advantageous for the seller who has the capacity to respond to any counter offer that the potential customer presents. The summary formula is: 


$$
I e=(Q 1-Q c t)+Q r_{1}+\cdots+Q r_{n}
$$

Where:

Ie: desired amount

Step 10: Calculation of the expected result with the product mix found.

$$
\mathrm{U}=\sum_{\mathrm{p}=1}^{\mathrm{n}}\left(Q_{n}\left(\mathrm{pu}_{n}-c v u_{n}\right)+\mathrm{Oi}\right)-(\mathrm{GO}+\mathrm{Gf})
$$

Where:

U: Utilities with the identified mixture.

Qn: Required amount of product sales "n".

$\mathrm{pu}_{\mathrm{n}}$ : Unit price of product " $\mathrm{n}$ " is submitted for analysis.

$\mathrm{cvu}_{n}$ : Unitary variable cost of product " $\mathrm{n}$ " is subjected to analysis.

Oi: Other income that the company can access.

GO: Operating expenses of the company for the period under analysis.

Gf: Financial expenses of the company for the period under analysis.

\section{Results}

Case study

The application of the aforementioned method is carried out in a machine workshop with CNC lathes (computer numerical control) to manufacture any type of product. The workshop is owned by a small entrepreneur. In the workshop under study, the machines are automated devices that are capable of manufacturing high diversity components without the direct help of humans. For this diversity, the company uses the instructions that are sent through an internal computer that facilitates their production a great variety of pieces with precision and speed.

Despite the wide range of possibilities, the analysis focuses on three products that represent approximately $80 \%$ of the orders that are frequently sent to the workshop. The choice of these three products simplifies the analysis and demonstrates the capacity of the method used, but the model can accommodate as many products as a company can produce but does require computerization in order to achieve accuracy and speed.

The primary data were collected by identifying them through interviews and a documentary review of the reports that were available in the analyzed workshop (See Table 1).

Table 1. Primary data.

\begin{tabular}{ccr}
\hline Indicators & Unity & Values \\
\hline Go & Dollar & $12,365.00$ \\
Gf & Dollar & $1,100.00$ \\
Oi & Dollar & $2,000.00$ \\
U & Dollar & $230,000.00$ \\
pu1 & Dollar & 11.00 \\
cvu1 & Dollar & 6.00
\end{tabular}




\begin{tabular}{ccr}
\hline Indicators & Unity & Values \\
\hline pu2 & Dollar & 18.00 \\
cvu2 & Dollar & 8.00 \\
pu3 & Dollar & 12.00 \\
cvu3 & Dollar & 5.00 \\
QtA & Piezas & 69,556 \\
QtB & Piezas & 32,134 \\
QtC & Piezas & 36,700 \\
\hline
\end{tabular}

With the previously identified data it was possible to calculate the desired amount, which reaches an amount of $\$ 241,465.00$. Once this value was determined, the amount of products needed to reach this desired amount was calculated. This was done as if it were going to sell a single product that the company produces and sells according to the orders from its customers (See Table 2).

Table 2. Calculation of the necessary units.

\begin{tabular}{ccc}
\hline Kind of product & Qn (to reach equilibrium point) & Qn (to achieve desired utility) \\
\hline A & 2,293 & 48,293 \\
B & 1,147 & 24,147 \\
C & 1,638 & 34,495 \\
\hline Total & 5,077 & 106,935 \\
\hline
\end{tabular}

Knowing the units needed to reach the desired amount, the percentage of installed capacity that would be occupied was established if only one product was made (See Table 3).

Table 3. Use of installed capacity if only one of these products was produced and sold.

\begin{tabular}{cc}
\hline Kind of product & Cdn \\
\hline A & $69.43 \%$ \\
B & $75.14 \%$ \\
C & $93.99 \%$ \\
\hline
\end{tabular}

The use of installed capacity as it was calculated before allows ordering from the highest to the lowest the products according to the most sales needed to reach the desired amount; while accounting for if that amount exceeds the operational capacity with which the company can work. In order to reduce it to the capacity allowed the company switches to the one that needs to sell the least to reach that objective. This process established an order of priorities that will be indispensable for the next steps (See Table 4).

Table 4. Priority of products according to the need to reach the desired amount.

\begin{tabular}{ccc}
\hline Kind of product & Qn & Priority \\
\hline A & 48,293 & 1 \\
B & 24,147 & 3 \\
C & 34,495 & 2 \\
\hline
\end{tabular}


The range between the product that needs to sell the most and the one that needs to sell the least is less than 24,147 . This range shows the number of units that can be mixed and that must be strictly adhered to, because redistributing more than that amount is economically impossible if the company wants to maintain a mix of products with recognized customers and with commitments not yet specified but that must be met in some way in volumes.

If the company decides to distribute the total range, that is, 24,147 ; then this is equal to "quantity ceded" that is distributed among the remaining products through a distribution coefficient expressed in decimal values (See Table 5).

Table 5. Accuracy of the distribution of the range by products.

\begin{tabular}{ccccc}
\hline Priority & Kind of product & Cdn & cfn & Qct \\
\hline 1 & A & $69.43 \%$ & & 24,147 \\
3 & B & $75.14 \%$ & $55.57 \%$ & 13,419 \\
2 & C & $93.99 \%$ & $44.43 \%$ & 10,728 \\
\hline
\end{tabular}

The adjustment coefficient that corresponds to each product is the result of subtracting the calculated and declared range from the needs of the first product (See Table 6).

Table 6. Determination of the adjustment coefficient corresponding to each product.

\begin{tabular}{ccc}
\hline Priority & Kind of product & Qrn \\
\hline 1 & A & 24,147 \\
3 & B & 6,709 \\
2 & C & 7,663 \\
\hline
\end{tabular}

With the previous results, the level of occupied installed capacity was evaluated by adding the percentages of the total capacity that each product represents. This leads to how much capacity was released (See Table 7).

Table 7. Used and released capacity.

\begin{tabular}{cc}
\hline Kind of producto & Cd \\
\hline A & $34.72 \%$ \\
B & $20.88 \%$ \\
C & $20.88 \%$ \\
\hline Occupied capacity (Cdo) & $76.47 \%$ \\
\hline Free capacity & $23.53 \%$ \\
\hline
\end{tabular}

With the calculated mixture the installed capacity would be occupied at $76.47 \%$, that is, approximately $23.53 \%$ is free. Calculating the expected result with this mixture determines that it can reach it (See Table 8). 
Table 8. Expected result with the calculated mixture.

\begin{tabular}{cccr}
\hline Kind of product & Quantity & $\begin{array}{c}\text { Margin of unitary } \\
\text { contribution }\end{array}$ & $\begin{array}{c}\text { Margin of contribution by } \\
\text { product }\end{array}$ \\
\hline A & 24,147 & 5.00 & $120,732.50$ \\
B & 6,709 & 10.00 & $67,093.56$ \\
C & 7,663 & 7.00 & $53,638.94$ \\
\hline
\end{tabular}

In the same way, the desired utility is calculated with the determined mixture (See Table 9).

Table 9. Desired utility with the calculated mixture.

\begin{tabular}{cccc}
\hline Kind of product & Quantity & $\begin{array}{c}\text { Margin of unitary } \\
\text { contribution }\end{array}$ & $\begin{array}{c}\text { Margin of contribution by } \\
\text { product }\end{array}$ \\
\hline A & 24,147 & 5.00 & $120,732.50$ \\
B & 6,709 & 10.00 & $67,093.56$ \\
C & 7,663 & 7.00 & $53,638.94$ \\
Qt & 38,519 & & $241,465.00$ \\
Oi & & $2,000.00$ \\
Go & & $12,365.00$ \\
Gf & & $1,100.00$ \\
\hline Utilities with the mixture & & $\mathbf{2 3 0 , 0 0 0 . 0 0}$ \\
\hline
\end{tabular}

The table shows that the desired profits are achieved at only $76.47 \%$ of the installed capacity. Which means that if there is more demand, the company can expand its profits.

\section{Discussion}

The present study aims to highlight the role of economic and financial information in the preparation of negotiations. The importance of the preparation of trade negotiations based on economic and financial techniques lies in their descriptive capacity, in the estimated nature of decision-making, and in the formulation of useful value judgments that reduce uncertainty and maximize objectives (de Lima et al., 2018; Essa et al., 2018; Laureth et al., 2018; Van den Abbeele et al., 2009). These arguments make clear the need for a method capable of providing timely and objective information for the preparation and subsequent behavior in a negotiating process.

The key contribution of this study to the negotiation literature is the development and empirical testing of a method that is based on the cost - volume - benefit analysis that gives small entrepreneurs the information on the right product mix that must be negotiated and how to take advantage of the installed capacities to produce it. All of which facilitates the negotiating behavior, improves the results of the negotiation, and allows an accurate procedure in obtaining the improvement of business performance. 
In general, the results support the literature that argues economic and financial information can help achieve better results in the negotiating process by positively influencing the behavior of negotiators by reducing the adverse impact of uncertainty on behavior that in turn should have a positive influence on the results obtained (Chang et al., 2013; Drake \& Haka, 2008; Essa et al., 2018; Van den Abbeele et al., 2009). With the calculated product mix, internal decisions can be made in order to use the installed capacities appropriately to achieve the company's objectives. With this information, a negotiation process can be developed with the clarity of what needs to be achieved as a negotiated result so that it contributes to what is desired and is convenient for small entrepreneurs and the company as a whole.

The proposed method has administrative implications for small entrepreneurs, since it involves the control and analysis of the influential variables in order to prepare their negotiation processes correctly.

\section{Conclusions}

The proposed method solves the complicated issue of scientifically determining the right mix of products in a negotiating process. Further, it provides entrepreneurs a large space for decision-making by facilitating the proposal of multiple alternatives that allow the negotiator to react quickly to the new counter offers from clients. Now, these offers can be analyzed immediately when this method is automated and is ready to create infinite decision trees.

The proposed method favors small entrepreneurs to plan, execute, and control the negotiation process and thus have a guide to a realistic negotiation process that adapts to the conditions of the company.

\section{References}

Agndal, H. (2007). Current trends in business negotiation research. An overview of articles published 1996-2005. In Stockholm School of Economics (Ed.), SSE/EFI Working Paper Series in Business Administration.

Agndal, H., Åge, L.-J., \& Eklinder-Frick, J. (2017). Two decades of business negotiation research: an overview and suggestions for future studies. Journal of Business \& Industrial Marketing, 32(4), 487-504. doi:10.1108/JBIM-11-2015-0233

Alavoine, C. (2012). You Can't Always Get What You Want: Strategic Issues in Negotiation. Procedia - Social and Behavioral Sciences, 58, 665-672. doi:10.1016/j.sbspro.2012.09.1044

Alavoine, C., \& Estieu, C. (2015). You can't always Get what you Want: Strategic Issues in Negotiation Part 2. Procedia - Social and Behavioral Sciences, 207, 335-343. doi:10.1016/j.sbspro.2015.10.103

Alvarez, C. M. O., Taylor, K. A., \& Gomez, C. (2017). The effects of Hispanic bilinguals language use and stereotype activation on negotiations outcomes. Journal of Business Research, 72, 158-167. doi:10.1016/j.jbusres.2016.10.009 
Baek, J.-G., \& Kim, C. O. (2007). Learning single-issue negotiation strategies using hierarchical clustering method. Expert Systems with Applications, 32(2), 606-615. doi:10.1016/j.eswa.2006.01.045

Brett, J., \& Thompson, L. (2016). Negotiation. Organizational Behavior and Human Decision Processes, 136, 68-79. doi:10.1016/j.obhdp.2016.06.003

Clenney, E. F., Maurer, T. J., \& Miles, E. W. (2013). Becoming a Negotiator: A Proposed Negotiation Skill Development Complexity Model. Academy of Management Proceedings, (1), 11509. doi:10.5465/ambpp.2013.11509abstract

Côté, S., Hideg, I., \& van Kleef, G. A. (2013). The consequences of faking anger in negotiations. Journal of Experimental Social Psychology, 49(3), 453-463. doi:10.1016/j.jesp.2012.12.015

Chang, L. J., Cheng, M. M., \& Trotman, K. T. (2013). The effect of outcome and process accountability on customer-supplier negotiations. Accounting, Organizations and Society, 38(2), 93-107. doi:10.1016/j.aos.2012.12.002

Chapman, E., Miles, E. W., \& Maurer, T. (2017). A proposed model for effective negotiation skill development. Journal of Management Development, 36(7), 940-958. doi:10.1108/JMD-01-2016-0002

Chuah, S.-H., Hoffmann, R., \& Larner, J. (2014). Chinese values and negotiation behaviour: A bargaining experiment. International Business Review, 23(6), 1203-1211. doi:10.1016/j.ibusrev.2014.05.002

De Dreu, C. K. W., Weingart, L. R., \& Kwon, S. (2000). Influence of social motives on integrative negotiation: A meta-analytic review and test of two theories. Journal of Personality and Social Psychology, 78(5), 889-905. doi:10.1037/0022-3514.78.5.889

de Lima, J. D., Ferro, W. A., Bortoluzzi, S. C., Puttow Southier, L. F., \& DBatistus, a. R. (2018). Uma proposta de ampliação na análise custo-volume-lucro por meio das análises de sensibilidade e de cenários,. Exacta, 16(2), 21-41. doi:10.5585/ExactaEP.v16n2.7214

Domínguez Rodríguez, K. M., \& Téllez Sánchez, L. (2011). Sistema de apoyo a la toma de decisiones en el proceso de negociación comercial. Ciencias Holguín, 22(3), 1-14.

Drake, A. R., \& Haka, S. F. (2008). Does ABC Information Exacerbate Hold-Up Problems in Buyer-Supplier Negotiations? The Accounting Review, 83(1), 29-60. doi:10.2308/accr.2008.83.1.29

Essa, S. A. G., Dekker, H. C., \& Groot, T. L. C. M. (2018). Your gain my pain? The effects of accounting information in uncertain negotiations. Management Accounting Research. doi:10.1016/j.mar.2018.02.002

Fay, S., Xie, J., \& Feng, C. (2015). The Effect of Probabilistic Selling on the Optimal Product Mix. Journal of Retailing, 91(3), 451-467. doi:10.1016/j.jretai.2015.01.004

Fernandes, R., Gouveia, J. B., \& Pinho, C. (2012). Product mix strategy and manufacturing flexibility. Journal of Manufacturing Systems, 31(3), 301-311. doi:10.1016/j.jmsy.2012.02.001

Fisher, R., Ury, W., \& Patton, B. (2011). Getting to Yes: Negotiating Agreement without Giving in (3rd ed.). New York, NY: Penguin Books.

Flint., P. J. (1990). Principios y Técnicas de Negociación Internacional. (1ª ed.). Lima: ALACCI. 
Forgas, J. P. (1998). On Feeling Good and Getting Your Way: Mood Effects on Negotiator Cognition and Bargaining Strategies. 74, 3, 565-577. doi:10.1037//00223514.74.3.565

Ganesan, S. (1993). Negotiation Strategies and the Nature of Channel Relationships. Journal of Marketing Research, 30(2), 183-203. doi:10.2307/3172827

García Delgado, D., \& Ortiz Torres, M. (2014). Sobre la negociación de los productos biotecnológicos con intangibles asociados. Biotecnología Aplicada, 31, 297-303.

García Vidal, G. (2006). Contribución teórico-profesional para la administración. (Tesis en opción al grado científico de Doctor en Ciencias Económicas.), Universidad de Oriente, Santiago de Cuba.

Geiger, I. (2017). A model of negotiation issue-based tactics in business-to-business sales negotiations. Industrial Marketing Management, 64, 91-106. doi:10.1016/j.indmarman.2017.02.003

Gong, Z., \& Hu, S. (2008). An economic evaluation model of product mix flexibility. Omega, 36(5), 852-864. doi:10.1016/j.omega.2006.04.008

Gunia, B. C., Brett, J. M., \& Gelfand, M. J. (2016). The science of culture and negotiation. Current Opinion in Psychology, 8, 78-83. doi:10.1016/j.copsyc.2015.10.008

Holmes, Y. M., Beitelspacher, L. S., Hochstein, B., \& Bolander, W. (2017). "Let's make a deal:" Price outcomes and the interaction of customer persuasion knowledge and salesperson negotiation strategies. Journal of Business Research, 78, 81-92. doi:10.1016/j.jbusres.2017.04.009

Laureth, S. V., Wernke, R., Heberle, É. L., \& Rufatto, I. (2018). Análise custo/volume/lucro aplicada em supermercado de pequeno porte: estudo de caso. Brazilian Journal of Development, 4(3), 863-885.

Linhares, A. (2009). Theory of constraints and the combinatorial complexity of the product-mix decision. International Journal of Production Economics, 121(1), 121-129. doi:10.1016/j.jpe.2009.04.023

Lumineau, F., \& Henderson, J. E. (2012). The influence of relational experience and contractual governance on the negotiation strategy in buyer-supplier disputes. Journal of Operations Management, 30(5), 382-395. doi:10.1016/j.jom.2012.03.005

Mason, M. F., Wiley, E. A., \& Ames, D. R. (2018). From belief to deceit: How expectancies about others' ethics shape deception in negotiations. Journal of Experimental Social Psychology, 76, 239-248. doi:10.1016/j.jesp.2018.02.013

Miller, O. (2014). The Negotiation Style: A Comparative Study between the Stated and in- Practice Negotiation Style. Procedia - Social and Behavioral Sciences, 124, 200-209. doi:10.1016/j.sbspro.2014.02.478

Peleckis, K. (2014). International Business Negotiations: Innovation, Negotiation Team, Preparation. Procedia - Social and Behavioral Sciences, 110, 64-73. doi:10.1016/j.sbspro.2013.12.848

Răscolean, I., \& Rakos, I.-S. (2017). Cost - Volume - Profit Analysis - An Instrument of Managerial Control of the Economic Entities in the Extractive Industry. "Ovidius" University Annal, XVII(2), 627-632.

Ribbink, D., \& Grimm, C. M. (2014). The impact of cultural differences on buyer-supplier negotiations: An experimental study. Journal of Operations Management, 32(3), 114126. doi:10.1016/j.jom.2014.01.004 
Ribeiro Alves da Silva, Í. D., Figueirêdo Cireno, M. E. D., \& Santana Bonfim, V. W. (2017). Análise custo-volume-lucro na produção de queijo do empreendimento agropecuário JC. ReAC - Revista de Administração e Contabilidade, 9(3), 55-67.

Richardson, C., \& Rammal, H. G. (2018). Religious belief and international business negotiations: Does faith influence negotiator behaviour? International Business Review, 27(2), 401-409. doi:10.1016/j.ibusrev.2017.09.007

Said, H. A. (2016). Using Different Probability Distributions for Managerial Accounting Technique: The Cost-Volume-Profit Analysis. Journal of Business and Accounting, 9(1), 3-24.

Sánchez-Anguix, V., Julián, V., Botti, V., \& García-Fornes, A. (2013). Studying the impact of negotiation environments on negotiation teams' performance. Information Sciences, 219, 17-40. doi:10.1016/j.ins.2012.07.017

Saorín-Iborra, M. C., \& Cubillo, G. (2018). Supplier behavior and its impact on customer satisfaction: A new characterization of negotiation behavior. Journal of Purchasing and Supply Management. doi:10.1016/j.pursup.2018.03.002

Scalzo, G., \& García Álvarez, S. (2018). El Management como práctica: una aproximación a la naturaleza del trabajo directivo. Empresa y Humanismo, 21 (1), 95119.

Stevens, C. K., \& Gist, M. E. (1997). Effects of Self-Efficacy and Goal-Orientation Training on Negotiation Skill Maintenance: What are the Mechanisms? Personnel Psychology, 50(4), 955-978. doi:10.1111/j.1744-6570.1997.tb01490.x

Tsai, W.-H., Chen, H.-C., Leu, J.-D., Chang, Y.-C., \& Lin, T. W. (2013). A product-mix decision model using green manufacturing technologies under activity-based costing. Journal of Cleaner Production, 57, 178-187. doi:10.1016/j.jclepro.2013.04.011

Van den Abbeele, A., Roodhooft, F., \& Warlop, L. (2009). The effect of cost information on buyer-supplier negotiations in different power settings. Accounting, Organizations and Society, 34(2), 245-266. doi:10.1016/j.aos.2008.05.005

Wiltermuth, S. S., Raj, M., \& Wood, A. (2018). How perceived power influences the consequences of dominance expressions in negotiations. Organizational Behavior and Human Decision Processes, 146, 14-30. doi:10.1016/j.obhdp.2018.02.002

Yuan, F.-C. (2009). The use of a fuzzy logic-based system in cost-volume-profit analysis under uncertainty. Expert Systems with Applications, 36(2, Part 1), 1155-1163. doi:10.1016/j.eswa.2007.11.025

Zohar, I. (2015). "The Art of Negotiation" Leadership Skills Required for Negotiation in Time of Crisis. Procedia - Social and Behavioral Sciences, 209, 540-548. doi:10.1016/j.sbspro.2015.11.285 